\title{
Marriage and Divorce: Changes and their Driving Forces
}

\author{
Betsey Stevenson \\ The Wharton School, University of Pennsylvania \\ Justin Wolfers \\ The Wharton School, University of Pennsylvania \\ CEPR, IZA and NBER
}

February 2007

Working Paper 2007-03

http://www.frbsf.org/publications/economics/papers/2007/wp07-03bk.pdf

The views in this paper are solely the responsibility of the authors and should not be interpreted as reflecting the views of the Federal Reserve Bank of San Francisco or the Board of Governors of the Federal Reserve System. 


\title{
Marriage and Divorce: Changes and their Driving Forces
}

\author{
Betsey Stevenson \\ The Wharton School, University of Pennsylvania \\ betsey.stevenson@wharton.upenn.edu \\ http://bpp.wharton.upenn.edu/betseys
}

\author{
Justin Wolfers \\ The Wharton School, University of Pennsylvania \\ CEPR, IZA and NBER \\ jwolfers@wharton.upenn.edu \\ www.nber.org/ jwolfers
}

\begin{abstract}
We document key facts about marriage and divorce, comparing trends through the past 150 years and outcomes across demographic groups and countries. While divorce rates have risen over the past 150 years, they have been falling for the past quarter century. Marriage rates have also been falling, but more strikingly, the importance of marriage at different points in the life cycle has changed, reflecting rising age at first marriage, rising divorce followed by high remarriage rates, and a combination of increased longevity with a declining age gap between husbands and wives. Cohabitation has also become increasingly important, emerging as a widely used step on the path to marriage. Out-of-wedlock fertility has also risen, consistent with declining "shotgun marriages". Compared with other countries, marriage maintains a central role in American life. We present evidence on some of the driving forces causing these changes in the marriage market: the rise of the birth control pill and women's control over their own fertility; sharp changes in wage structure, including a rise in inequality and partial closing of the gender wage gap; dramatic changes in home production technologies; and the emergence of the internet as a new matching technology. We note that recent changes in family forms demand a reassessment of theories of the family and argue that consumption complementarities may be an increasingly important component of marriage. Finally, we discuss how these facts should inform family policy debates.
\end{abstract}

JEL Codes: D1, H31, I3, J1, K36, N3

Keywords: Marriage, divorce, fertility, cohabitation, remarriage, economics of the family, demography.

The authors would like to thank Leora Friedberg, Christopher Jencks, William Johnson, Lawrence Katz, John Knowles, Robert Pollak, Timothy Taylor, and participants in Wharton's applied economics seminar for useful comments. Adam Isen, Sam Proctor, Rachel Schwartz, and Hao Wang provided excellent research assistance. 
The family is not a static institution. In recent decades, marriage rates have fallen, divorce rates have risen, and the defining characteristics of marriage have changed. The economic approach to the family seeks to explain these trends by reference to models that can also explain how and why families form. Gary Becker's 1981 Treatise on the Family proposed a theory based on "production complementarities”, in which husband and wife specialize in the market and domestic spheres, respectively, and hence are more productive together than apart. Production complementarities also arise in the production and rearing of one's own children. However, production complementarities—at least as initially described—are decreasingly central to modern family life. Increased longevity and declining fertility mean that most of one's adult life is spent without one's own children in the household, and the rise in marital formation at older ages, including re-marriage, means that many families form with no intention of producing children. Moreover, increases in female labor force participation suggest that household specialization has either declined or taken on a different meaning.

These changes have come about as what is produced in the home has been dramatically altered both by the emergence of labor-saving technology in the home and by the development of service industries that allow much of what was once provided by specialized homemakers to be purchased in the market. The availability of birth control and abortion has affected the potential consequences of sex both in and out of marriage, while changes in divorce laws have altered the terms of the marital bargain. These forces also have important feedback effects, changing the pool of marriageable singles across the age distribution, thereby affecting search, marriage, remarriage, and the extent of "churning" in the marriage market.

To remain relevant to the $21^{\text {st }}$ century, the theory of the family will need to push beyond the production of own children and traditional notions of specialization, and must seek to uncover the forces that yield the modern family form. This may mean re-conceiving the notion of household production or, as we argue, extending models of the family beyond the notion of a household-based firm, and toward emphasizing motivations such as consumption, complementarities, and insurance as 
central to marriage. Furthermore, the theory of the family as originally developed was a theory of household formation rather than a theory of legal marriage. Couples have become increasingly likely to form households without entering into a marriage, adding a new dimension for considering decisions surrounding family formation. This article lays the groundwork for a reconsideration of the theory of the family, by describing the tremendous changes in family forms, pointing to some of their driving forces, and suggesting ways of expanding our thinking about the family to better understand its future.

\section{Trends in Marriage and Divorce}

Figure 1 lays out some facts about marriage and divorce in the United States over the last 150 years: the divorce rate - measured as the number of new divorces each year, on a per capita basis—-has risen, while the marriage rate has fluctuated around a relatively stable mean. The timing of these changes suggests that social and economic factors strongly influence the marriage market. Marriage rates rose during, and in the wake of, the two World Wars and fell during the Great Depression. The divorce rate fell during the Depression and spiked following World War II.

Developments since the 1960s appear to reflect more subtle influences, and have been the focus of heated political debate as the heyday of marriage gave way to rapid social change. Divorce rates rose sharply, doubling between the mid-1960s and the mid-1970s. During this period, family life was potentially altered by many factors: the rise of the women’s liberation movement, the sexual revolution, the Supreme Court's granting of marriage as a "fundamental" right under the U.S. Constitution and thus the abolition of laws restricting marriage between races, the elimination in many states of fault-based divorce, and a sharp rise in women's labor force participation. Yet when viewed over the longer time period, we see that while the 1970s had exceptionally high divorce rates, the low divorce rates in previous decades were also somewhat exceptional. Fitting a simple trend line to the 
divorce rate between 1860 and 1945 (excluding the post-World War II surge in divorce), as shown in Figure 1, suggests that some of the run-up in divorce in the latter third of the 20th century reflects the divorce rate reverting to levels consistent with earlier trends, following unusually low divorce in the 1950s and early 1960s. Indeed, based on extrapolation, family scholars as early as the turn of the last century had predicted future divorce rates like those actually witnessed in the 1980s (Coontz, 2005). While the 1970s overshot the trend, the subsequent fall in divorce has put the divorce rate back on the trend-line and by 2005 the annual divorce rate projected by the pre-1946 trend is quite close to actual divorce rates.

Figure 1 also points to a remarkable and often overlooked fact: the divorce rate per thousand people actually peaked in 1981, and has been declining over the ensuing quarter century. The divorce rate in 2005-3.6 divorces per thousand people — is at its lowest level since 1970. The number of people entering marriage, as a proportion of the population, in the U.S. has also been falling for the past 25 years, and the marriage rate is currently at its lowest point in recorded history. Marriage rates rose as the divorce rate rose, but reached an earlier peak in 1972. Yet even when measuring the number of divorces relative to the "at-risk population" (that is, those who are currently married), we see a similar decline in the divorce rate over the last 25 years falling from a peak of 22.8 divorces per 1,000 married couples in 1979 to 16.7 divorces in 2005. The sustained decline in divorce over the past quarter century provides an ideal testing ground for assessing the validity of alternative theories of why the divorce rate rose in the late 1960s and into the 1970s; unfortunately, such tests are mostly absent from the existing literature.

Figure 2 analyzes data from marital histories to assess the fate of first marriages, grouping them by the decade in which the wedding occurred. For those marriages that occurred in the 1950s through the 1970s, we know a lot about their eventual outcomes, and the figure clearly shows that the probability of divorce before each anniversary rose for each successive marriage cohort until the 1970s. For marriages that occurred in the 1970s, 48 percent had dissolved within 25 years, roughly 
confirming—for this specific cohort—-the popular claim that "half of all marriages end in divorce."1 Yet for first marriages that occurred in the 1980s, the proportion that had dissolved by each anniversary was consistently lower, and it is lower again for marriages that occurred in the 1990s. While it will take several more decades for the long-term fate of recent marriages to be realized, it appears likely that fewer than half of these recent marriages will dissolve.

Much of the concern over the high divorce rates in the 1970s stemmed from the impact of divorce on children. Indeed, as divorce rose in the 1960s and 1970s so too did the number of children involved in each divorce. In the 1950s, the average divorce involved 0.78 children; by 1968 that number had risen to 1.34. However, since 1968, the average number of children involved in each divorce has fallen dramatically, and in 1995 the average was 0.91, only slightly above the 1950 average. Similar patterns are evidence in data on the proportion of divorces that involve any children. While the collection of detailed national divorce statistics ceased in 1995, recent data from individual states suggest that the number of children involved in divorce has continued to decline over the subsequent decade.

There exists substantial controversy—and uncertainty—about the impact of divorce on children. While children from divorced households fare worse along a range of outcomes than those from intact households, this observation does not speak to the policy-relevant question of whether those children would have been better off if their parents had not divorced. The conflict in these households may be such that children are actually better served by their parents divorcing. Thus, comparisons of the "happily married" with the "unhappily divorced" are likely irrelevant for those choosing between an unhappy marriage and an unhappy divorce. Moreover, the difficulty in

\footnotetext{
${ }^{1}$ There are many alternative sources for this claim, several of which are based on quite dubious assumptions. The simplest (and most problematic) approach is to take the ratio of the number of divorces to the number of marriages, which would correspond to the proportion of marriages ending in divorce if the marriage market were in a steady state (an assumption that Figure 1 shows to be markedly false). So-called "life tables" offer a somewhat more refined, but related approach, adding age-specific divorce rates to come up with the probability that a marriage ends in divorce. This approach effectively simulates the likely course of a cohort were age-specific divorce rates measured at a point in time to remain unchanged. Yet as Figure 2 makes clear, there are strong cohort-specific influences on these rates, confounding such an inference.
} 
establishing a causal link between divorce decisions and children's outcomes is compounded by the possibility that the type of parents and households that end up divorced are likely different from those who do not. These differences may themselves lead to worse outcomes for children even if the parents were to remain married. Additionally, unobserved negative shocks to the family may both lead to divorce and negative outcomes for children, further confounding attempts at causal inference.

With entry into marriage falling, but exit through divorce also falling, what has happened to the proportion of the population living in a married relationship? Figure 3 shows the proportion of the population currently married, by age, for every other decade, from 1880 to the present. Four striking patterns emerge from this analysis. First, the proportion married at each age has been surprisingly stable over more than a century; the pattern in 1980, for instance, is remarkably similar to that in 1880. Second, consistent with our earlier analysis, the 1960s were unusual, reflecting not only more marriage, but earlier marriage. Third, the data for 2000 suggest a very different pattern, with marriage less prevalent among young adults, but more prevalent among those at older ages. This trend toward rising age at first marriage represents both a return to, and a departure from, earlier patterns. The return to earlier patterns is the later age at which men first marry; in 1890, the median age at which men first married was 26, declining to 23 by the mid-1950s, and then returning to 27 in 2004 . The departure is that the age gap between men and women has declined through the past century, with the median age at which women first marry rising from 22 in 1890 to 26 in 2004 (U.S. Census Bureau, 2005).

This shrinking gap between the ages of husbands and wives helps explain the fourth striking fact in Figure 3: those over 65 are now much more likely to be married than at any other time in the past. In fact, those over 65 are now as likely to be married as are those aged 16 to 65 . The larger proportion of people married at older ages reflects greater life expectancy for both men and women and a decreasing gap in the difference between men's and women’s life expectancy. Additionally, some of this increase in the proportion of those over 65 who are married stems from an increase in the 
proportion marrying at older ages, with these later-age marriages potentially being facilitated by a thicker remarriage market in recent decades that allowed greater remarriage following either divorce or the death of a spouse.

This changing age profile of marriage also points to the declining role of fertility and childrearing in married life. In 1880, 75\% of married people lived in a household in which their own children were present. That proportion has fallen steadily over the past 125 years, and by 2005 only $41 \%$ of married people had their own children present in their household. This dramatic shift reflects the confluence of many factors, including declining fertility, increased longevity, increasing rates of marriage at later, post-childbearing ages, rising non-marital births, and rising divorce.

\section{The Marital Life Cycle}

Basic statistics on marriage and divorce rates, or age at first marriage, no longer paint a complete picture of modern family life. Marriage is now likely to be preceded by cohabitation, and in many cases may be succeeded by divorce, remarriage, and for some people further "churn” may follow. Figure 4 illustrates, showing marital status through the life cycle for the 1940-45 birth cohorts—-the most recent group for which complete marital histories through to age 55 are available.

By age 30, six out of seven of these men and women had entered into a first marriage; onesixth of these marriages had already ended, and of these, one-half had subsequently remarried. By age 45, only 7 percent remained never married and around one-third of first marriages had ended. The share of the previously married population that had subsequently remarried remained around one half. By age 55, all but 5 percent of this cohort had married at some point, and 53 percent of the population remained in intact first marriages.

Table 1 provides further detail on life cycle patterns both comparing the 1940-45 cohort with the cohort born a decade later and exploring variation by demographic group in the more recent cohort. 
In order to allow us to explore this younger cohort (those born in 1950-55), Table 1 assesses outcomes through to age 45. Thus, the first two columns compare the 1940-45 birth cohort discussed in the previous paragraph with the subsequent cohort born between 1950 and 1955 . These data suggest that by age 45 the more recent cohort was less likely to have married and more likely to have divorced than the preceding cohort. Moreover, conditional on divorcing, those in the more recent cohort exit their marriages faster and have slightly lower, but still high, levels of remarrying within five years of divorce. Based on life patterns like these, Cherlin (1981) described the increasingly typical life course as “marriage, divorce, remarriage.”

As Ellwood and Crane (1990) have noted in this journal (and as a huge literature in sociology has discussed) there is a stark racial divide in family structure. This difference is evident in Table 1. This racial divide is driven almost entirely by lower and slower entry into marriage by blacks, rather than higher or more rapid divorce. By age 45, nearly one-in-four blacks born between 1950 and 1955 had never married, while the equivalent statistic for whites was one-in-ten. Yet, among those marrying, divorce rates for blacks and whites were similar, and blacks in fact spent more time in their marriages before divorce than whites. As with first marriage, re-entry into marriage among blacks was both rarer, and typically slower than that of whites.

Figure 5 shows that for much of the first half of the twentieth century, blacks were in fact more likely than whites to marry. In the 1940s and 1950s, the proportion of whites who were married rose, closing and ultimately reversing the racial gap in marriage. The incidence of marriage has subsequently declined for all groups, but most dramatically among blacks: 71 percent of blacks born in 1945 had married by age 25, compared with 51 percent of those born in 1955 .

While the changing racial gap in the incidence of marriage largely reflects differences in entry into marriage, not divorce rates, differences across education levels reflect an emerging "divorce gap.” Table 1 highlights a 10 percentage point gap between college graduates and those with less than a college education in the probability of a first marriage surviving to age 45, and the higher divorce 
propensity among those without a college degree is too large to simply reflect their earlier entry into marriage. Furthermore, conditional on divorcing, those without a college degree are less likely to remarry, and if they do remarry, they are again more likely to divorce.

Although the data in Table 1 show similar marriage rates across education levels, these data hide interesting differences which become evident only when the data are further disaggregated by gender. For men, those with a college degree are 3 percentage points more likely to have married by age 45 than those without, while female college graduates are 3 percentage points less likely to have married. Yet, marriage rates for college-educated women have been rising over time and — while still below those of their less-educated peers - are at an historic high. In the late nineteenth century almost half of all college-educated women never married (Coontz, 2005). In the 1960 census, 29 percent of the college-educated women in their sixties had never married. By contrast, four decades later, the equivalent proportion was only 8 percent. Indeed, highly educated women are now as likely_and may eventually be more likely_to marry than less educated women. The difficulty in comparing marriage rates across education groups is that highly-educated women marry much later than do those with less education, so comparisons early in the life span tend to show that those with less education are more likely to have married. Even so, the 2004 American Community Survey suggests that college-educated women between the ages of 35 and 40, were as likely to have ever married as those without a college degree and were 10 percentage points more likely to be currently married than their less educated peers.

Table 1 shows that divorced women are less likely than divorced men to remarry-a fact that has been pointed to by scholars concerned with women's poverty following divorce. Once again, this average masks big differences in remarriage rates by education (not shown in Table 1). Among those without a college degree, divorced women are as likely as divorced men to remarry: 71 percent of both groups have remarried by age 45. In contrast, nearly three-quarters of college-educated divorced men remarry, compared with two-thirds of college-educated divorced women. Counter to the conventional 
wisdom that it is women with the least resources that are less likely to remarry, it appears to be those best equipped to cope outside of marriage who are more likely to eschew marriage the second time around.

\section{Cohabitation}

So far we have discussed patterns in formal marriage. Yet the decision to form a household with another is increasingly becoming decoupled from the decision to marry. Indeed, in recent decades, cohabitation has emerged as an important institution, as both a precursor to, and sometimes a substitute to, marriage. This decoupling of domestic arrangements from the legal (and social) status of relationships raises important new questions for economic analysis of the family, as early models treated marriage and household formation almost identically. Yet these labels also have substantive economic content, determining the default allocation of property rights following separation, tax treatment of the couple, and eligibility for both social programs and employment-related family benefits. Growing social acceptance of non-marital relationships and the changing legal institutions surrounding marriage, leads one to ask: what distinguishes marital relationships from cohabiting relationships, and how has this distinction changed?

However empirical analysis related to these questions is beset by a simple difficulty: until recently, few available data collections contain information on non-marital cohabiting relationships. The available data documenting the rise of cohabitation suggests that levels of cohabitation were low prior to 1970 and that they have grown at a roughly constant rate since then, with perhaps faster growth in the past decade. This assessment comes from three sources. First, in 1995 the Current Population Survey started allowing people to identify themselves as an "unmarried partner" of the householder (rather than just "partner/roommate"). These data suggest that cohabitation rates among adults have risen from 2.9 percent in March 1995 to 4.7 percent in March 2005. Second, a similar 
change was made for the Census, which recorded a 3.5 percent cohabitation rate among adults in 1990 and 5 percent in 2000, one-in-nine of whom were same-sex couples (with roughly equal numbers involving male and female same-sex couples). ${ }^{2}$ Finally, for earlier periods, Fitch et al. (2005) analyze Census data and calculate a proxy measure of cohabitation, the number of persons of the opposite sex sharing living quarters ("POSSLQ”), documenting that there was virtually no rise in cohabitation between 1880 and 1970, followed by roughly constant growth in the years hence.

The 2002 National Survey of Family Growth found that 50 percent of women aged 15 to 44 had cohabited at some point and 9 percent were currently cohabiting. In the United States, cohabitation has thus far largely been a stepping stone toward marriage, with most people who cohabit either ending their relationship or marrying within a few years. Among those currently cohabiting, the vast majority expect their cohabitation to lead to marriage. Indeed, 34 percent enter cohabitation having announced a plan to marry. Even among the remaining two-thirds who enter cohabitation without being engaged, 36 percent were “almost certain” that they would marry their current partner, and another 46 percent thought that there was either "a pretty good chance” or "a 50-50 chance” of marrying their partner (National Survey of Fertility Growth, 2002). Contrary to stereotypes, men and women express similar expectations about their likelihood of marrying their cohabiting partners. Such beliefs regarding their future likelihood of marriage, however, are not always warranted. Among those couples who were cohabiting in January 1997, slightly more than half were no longer together 5 years later, and only a quarter had married.

While most cohabitations do not end in marriage, most marriages are preceded by cohabitation. Among those entering first marriages in the early 2000s, 59 percent had cohabited with their future spouse prior to marriage. Pre-marital cohabitation with one's future spouse is even more common among those who have previously divorced, with 75 percent of those remarrying in the early 2000s

\footnotetext{
${ }^{2}$ The 1990 Census cohabitation estimates need to be interpreted with some caution as the Census "corrected" responses by same-sex couples, either recoding the gender of one partner, or their relationship status. For more on this issue, see the paper by Black, Sanders, and Taylor in this volume.
} 
preceding their wedding with a period of cohabitation. (Moreover, this differential is robust to controlling for the higher age of most remarriages.) This trend to pre-marital household formation may also explain some of the rise in measured age at first marriage. Cohabiting couples represent a bit more than half of all first marriages, and these couples typically entered into domesticity about two years prior to marriage, thus high recent rates of premarital cohabitation may explain up to a year of the rise in mean age at first marriage.

While it might seem that cohabiting before marriage should reduce uncertainty about the quality of a couple's match, U.S. couples who cohabit before marriage have been historically more likely to divorce than those who do not. This pattern may reflect differential selection into cohabitation, as those who live together prior to marriage may be doing so because they are less certain of the quality of their match, or because they stand to gain less from marriage (Lillard, Brien, and Waite, 1995; Brien, Lillard, and Stern, 2006). In other words, those who choose to cohabit may have been more likely to divorce even if they had not lived together first. Cohabitation may also be responsible for some of the reduction in divorce rates witnessed over the past 25 years as separations that previously occurred while legally married may now occur during pre-marital cohabitation. The difficulty in making any of these attributions convincingly lies in constructing a counterfactual: Would the cohabitating couple still have separated if they had married earlier?

Cohabitation is clearly evolving, and some couples are currently entering cohabitation as a permanent or semi-permanent state. Among those cohabiting in 2002, a little over one-fifth had been doing so for five years or more, indicating that some couples are treating cohabitation as a more permanent state. While for some the decision to cohabit may reflect a lower commitment to one's partnership, for others this choice may reflect a lower value of the institutional structure of marriage rather than a lower commitment. For instance, an increasing number of dual-career couples, combined with high marginal tax rates on secondary earners may face a "marriage penalty", while increasing social acceptance of cohabitation may have diminished social stigma. Additionally, the incremental 
value of formal marriage in enforcing intertemporal commitments is smaller when divorce laws allow one partner to unilaterally dissolve the relationship. Similarly, pre-nuptial contracts have reduced the role of family law as an important default for allocating property at divorce.

It remains an open question as to whether cohabitation might evolve from the largely transitional role it currently plays in the U.S. to being a viable alternative to marriage. Turning to international comparisons, as we do in the next section, we see that cohabitation is poised to become an important family form, in several comparable nations.

\section{International Comparisons}

Family life varies widely across industrialized nations. Table 2 shows that Americans marry, divorce, and remarry at rates higher than in most other countries with comparable income levels. This greater "churning" in marriage is reminiscent of the cross-country labor market literature, in which the United States is known for its greater labor market entry and exit.

Marriage appears to be more central and cherished in the United States than in many other countries. Italy is similar to the U.S. in many respects—both countries have low cohabitation rates and few consider marriage to be an outdated institution, although the United States is by far the greatest outlier in the low proportion agreeing with that sentiment. Yet a major difference arises when examining divorce rates. In Italy divorce rates are extremely low and those who divorce in Italy remain divorced (which accounts for why the proportion of the population "currently divorced" remains at levels similar to the United States). While Americans reveal their willingness to exit bad marriages in their high rates of divorce, only 43 percent agree that "divorce is usually the best solution when a couple can’t seem to work out their marriage options," compared with an overwhelming majority in every other country including Italy. 
Sweden provides a particularly stark counterpoint to the United States and Italy, and is an interesting example of the "Nordic model” of the family. Swedish marriage rates are low and cohabitation rates are high. Yet fertility—and particularly non-marital fertility—remains quite high, consistent with an emerging social norm in Sweden that childbirth and formal marriage need not be linked. Other high-income countries may be moving toward the Nordic model, albeit slowly. For instance, France, Canada, and the United Kingdom have cohabitation rates similar to Sweden and high rates of out-of-wedlock childbirth.

Another point in which the United States seems exceptional is the relatively young age at which women are giving birth. The age at which women have children has been rising in all the countries, and in 2002, the average age at child birth was over 30 in Italy and Sweden, and 29 or higher everywhere, save the United States where the average age was 27.

Earlier, we documented the declining importance of children to married life-at least for the United States, where today only a minority of married households include own children. The data in Table 2 suggest that this may be even more evident in other industrialized nations, where the trend toward out-of-wedlock childbirth is also paired with a greater proportion of women marrying at older (post-fertility) ages. For instance, in the U.S., Canada, the U.K., France, and Sweden, between a quarter and a third of marriages involved women at least 35 years old. In Italy the proportion was only 15\%, partially reflecting the country’s very low rate of remarriage. Moreover, aggregate fertilitywhether married or not-is currently quite low in many European nations, a fact that beyond portending changes in the family, points to a looming "demographic crisis” in many countries.

\section{The Driving Forces of Family Change}

The economic approach to the family seeks to explain how and why families form, and in so doing, this approach highlights the potential forces that change family formation. Couples marry, and 
stay married, when the gains from marriage exceed the gains from being single. These gains come from production complementarities (such as household specialization and the raising of one's children), the benefits of risk pooling, and from consumption complementarities (such as from the joint consumption of public goods and from shared leisure activities). Thus, reduced market discrimination against women and technological advances that allow much of what was once produced by skilledlabor in the home to be purchased or produced with little skill reduce the the benefits from specialization of spouses in the home and market spheres, thereby decreasing the gains from marriage. Simultaneously, increasing leisure time and wealth along with the changing landscape defining sexual relations potentially raises the gains from consumption complementarities. These changes in tastes, technology, and the institutional or legal environment have altered gains from marriage. With an eye to these drivers of family formation and dissolution, we now review some of the fundamental changes in the purpose, function, and form of family life over the past half century.

\section{The Technology of Birth Control}

The Economist (1999) cited the birth control pill as the invention that "defined the 20th century.” In 1960, the first birth control pill was approved by the FDA and diffused rapidly to married woman; by 1965, 41 percent of married women under 30 who used contraceptives were on "the pill” (Goldin and Katz, 2002). However, laws limiting the distribution to unmarried women slowed broader diffusion of the pill until the early 1970s, when such laws were finally overturned by the Supreme Court in Eisenstadt v. Baird. This ruling quickly facilitated distribution of the pill to unmarried women and by 1976, three-quarters of ever-contracepting single 18 and 19 year olds had used the pill (Goldin and Katz, 2002).

The birth control pill was an important innovation in two respects: it was far more effective than other forms of birth control and, unlike other forms of contraception, the pill allowed contraceptive decisions to be made privately by a woman, rather than jointly with her partner. In the 
early 1970s, women also gained greater access to abortion through the legalization of abortion by five states in 1970 and nationwide through the Supreme Court's decision in Roe v. Wade (410 U.S. 113) three years later. Both the birth control pill and abortion decreased the probability of an unwanted pregnancy. This improved control over fertility changed the timing of marriage and births, and also facilitated the increase in women's accumulation of human capital by reducing the risk of disruption to women's education or labor market plans.

The pill also reduced the cost of waiting to marry, by allowing sex outside of marriage with little fear of an unwanted pregnancy. The lower cost of delaying marriage led to longer courtships, and courtship was also more informative (due to greater sexual contact). Thus, those entering marriage did so with less uncertainty about their compatibility, thereby reducing the number of bad matches. One effect of this change was to lower the probability of divorce; another effect was to encourage others to wait longer to marry, as fears receded that those left unmarried by their mid-twenties would confront an adversely-selected set of potential spouses. Examining college-educated women, Goldin and Katz (2002) demonstrate that differential access to the pill across states and cohorts robustly predicts subsequently higher age at first marriage, lower divorce, and lower marriage rates. They also demonstrate qualitatively similar, albeit smaller, effects from the legalization of abortion.

While greater access to birth control and abortion did reduce unplanned pregnancies, out-ofwedlock births increased following these technological innovations. Akerlof, Yellen, and Katz (1996) address this puzzle by arguing that women’s newfound control over pregnancy increased pressure on them to engage in premarital sexual relations and reduced their ability to extract a commitment to marry in the event of a pregnancy. Thus, those who did not adopt the pill, or who suffered contraceptive failure, gained the option of choosing between abortion instead of pregnancy, but if choosing pregnancy, typically lost the offer of a subsequent "shotgun marriage.” Akerlof, Yellen, and Katz document a decline between the late 1960s and late 1980s in the percentage of parents marrying when faced with an out-of-wedlock pregnancy and argue that—at least in an accounting sense-this 
failure to marry subsequent to pregnancy explains much of the growth in out-of-wedlock births seen over this period.

While birth control has made sex safer in terms of an unwanted pregnancy, the emergence of AIDS has made sex riskier. Specifically, AIDS changes the benefit of sex within a monogamous relationship relative to that from casual sexual encounters, which may involve greater health risks, or costs of prevention through safe sex practices. Differences in infection and transmission rates across sub-groups also changes the costs of some pairings, and Francis (2006) provides intriguing evidence that greater knowledge of the risk of AIDS reduces the probability of men choosing same-sex partners, while increasing prevalence of same-sex partnerships among women. Recent improvements in HIV treatments have substantially reduced AIDS-related mortality and Lakdawalla, Sood, and Goldman (2006) provide evidence that access to these treatments partly undoes some of these trends.

\section{Household Technology}

The spread of indoor plumbing and electricity in the first half of the twentieth century, along with the myriad of household appliances that diffused throughout the last century (particularly in the 1950s and 1960s), led to vast increases in the productivity of housework. Homemakers suddenly had freezers, washing machines, dryers, steam iron, and a lucky few, dishwashers, at their disposal. Greenwood, Seshadri, and Yorukoglu (2005) document this rise in household appliances over the last century and cite evidence that the time required to clean a load of laundry fell from four hours using manual methods to only 41 minutes when aided by a 1940s era electric washing machine and dryer. These breakthroughs in the invention of household appliances heralded a new age of freedom for housewives, freeing them of the drudgery of household production and turning them into "household managers” of an electric army.

Electricity and household appliances are "labor-saving” in that one can now produce the same bundle of home-produced goods in less time. While substitution effects may lead to some increased 
consumption of home-produced goods, income effects from these time-saving advances may also be important, increasing the household's consumption of both home- and market-produced goods. Greenwood, Seshadri, and Yorukoglu (2005) suggest that the time-saving effects of these new technologies dominated, leading women to spend less time working in the home and more time in the market, thereby increasing female labor force participation.

Moreover, this technical change is unlikely to have been skill-neutral. Even basic tasks like laundry take much less skill with a modern washer and dryer. (Anyone who has tried to do laundry on a scrub board or rock knows that it is quite difficult!) In turn, this lower skill requirement has reduced the returns to specialization in home production. Indeed, this skill-substituting technical change parallels the decline in the field of home economics, the historically female-dominated subject devoted to developing skills such as sewing and cooking.

Additionally, a growing service sector and increasing commoditization have created ready market substitutes for products that were previously the exclusive domain of home producers. Perhaps most significantly, technological improvements in the mass production of food led to the increased availability of factory-prepared food. Cutler, Glaeser, and Shapiro (2003) credit these innovations with the 50 percent reduction in food preparation and clean-up times for both working and non-working women between 1965 and 1990.

These changes in household technology have implications for family formation. If the returns to specialization within a household fall, then the opportunity cost of remaining single rather than marrying falls. Moreover, in a time when men were specialized in market production, and household production required specialized labor inputs, it was not surprising that women with specialized market skills had less to gain from marriage, and were therefore less likely to marry. It is only as women have entered the labor market en masse that the education gap in marriage rates among women has closed.

Consider a further implication of these changes. Greenwood and Vandenbroucke (2005) credit technological progress with reducing the workweek from 70 hours in 1830 to 41 hours in 2002, and 
Aguiar and Hurst (2007) document a rise in leisure over the past 40 years that corresponds roughly to an additional 5-10 weeks of vacation per year. As the mix of household activities has shifted, optimal matching in the marriage market has likely changed. Thus, one might expect these changes to have made leisure and consumption complementarities more important drivers of matching than the production complementarities emphasized by Becker (1981). For instance, while Becker had predicted that those with high wage rates will tend to marry those with lower wage rates ("negative assortative mating”) because the benefits from the division of labor within a household can make the earning abilities of the man and the woman substitutes, this argument loses force in two-career couples. Thus, as marriage comes to be built more around consumption complementarities we might expect it to increasingly involve the pairing of those with similar income and interests (Lam, 1998).

An alternative complementarity arises from thinking about households as insurance units. While the increase in female labor force participation has reduced specialization in the home, it may have increased the benefit from household risk-sharing. As such, we may see a different form of negative assortative matching, as people seek spouses whose labor income risk is negatively correlated with their own.

\section{Changes in Wage Structures}

A large literature in labor economics (surveyed in the Spring 1997 issue of this journal) has documented increasing wage inequality since the 1970s. These changes reflect several factors, including: skill-biased technical change, a declining real value of the minimum wage, and the deunionization of the American workforce. Gould and Paserman (2003) argue that this change directly impacts marriage markets, raising the importance of "searching for Mr. Right.” That is, rising wage inequality has increased the returns to further search and thus increased the option value of remaining unmarried. Gould and Paserman test this effect of inequality on marriages rates by examining the consequences of differences across cities in the rates at which inequality grew through the 1970s and 
1980s. They find that in cities in which wage inequality rose fastest, the proportion of young women who were married fell quite dramatically. Indeed, their estimates suggest that this rising wage inequality may account for up to one-third of the decline in the marriage rate of 21 to 30 year old women.

Another important change in the wage structure derives from the decline in the gender wage gap. Blau and Kahn (2000) describe these changes as emanating from a decline in explicitly sexist personnel policies (partly driven by the increasing reach of anti-discrimination law), increased labor market experience among women (and increased returns to this experience), declining occupational segregation, and de-unionization. In the face of these trends, the comparative advantage of wives in home rather than market production has declined, driving an increasing share of men into home production, or reducing the value of specialization within marriage.

Beyond possibly reducing the attractiveness of marriage, the reduction in the wage gap may have other, subtle effects. For instance, Becker, Landes, and Michael (1977) explain the historically younger age at which women marry by noting that the specialized investments made by women in home economics were much less useful to singles. Indeed, as women have come to invest more in market skills, so too the age at which they choose to marry has drawn closer to parity with men. Caucutt, Guner, and Knowles (2002) argue that rising returns to labor market experience may also have important dynamic effects, raising the incentive for highly educated women to delay the timing of fertility in favor of developing stronger prospects in both labor and marriage markets.

The difficulty in empirically assessing the effects of changes in labor markets on family outcomes is that a strong reverse channel likely confounds any easy inference. For instance, women who forecast later or more fragile marriages may choose to invest more in their careers, leading to better labor force outcomes for women. As one example of such a dynamic, Johnson and Skinner (1986) find that women who anticipate a future divorce are more likely to participate in the labor 
market. Similarly, Stevenson (2006) finds that unilateral divorce laws led to an increase in labor force participation for both married and unmarried women.

\section{Changes in the Legal Structure of Marriage}

Governments set the parameters which define the family as a legal institution. These parameters define who is to be granted marriages, divorces, and parental rights, and articulate subsequent obligations. The law also provides a set of default property rights in case of separation or death, and defines families for the purposes of taxation and government programs.

In the U.S., the 1960s ushered in a wave of large-scale deregulation of the family. Consequently, the role that the government plays in deciding both who can marry and divorce has steadily diminished. In the 1950s some state legislatures began to repeal laws restricting marriage between racial groups. These anti-miscegenation laws were eliminated nationwide in 1967 by the Supreme Court ruling in Loving v. Virginia (388 U.S. 1). which argued that marriage was "one of the 'basic civil rights of man’” (in this issue, Fryer discusses patterns of interracial marriage over time). This ruling set the stage for further deregulation of marriage, including providing a legal challenge to state marriage bars for those deemed “unsuitable”, such as felons, the disabled, those with a low IQ, and “dead-beat dads". 3

Supreme Court rulings in the 1960s and 1970s also changed the nature of family relationships by eliminating many of the legal distinctions stemming from the marital status of a child's parents. In 1968 the Supreme Court ruling in Levy v. Louisiana (391 U.S. 68) granted equal protection under the Fourteenth Amendment to illegitimate children. Five years later, the 1973 ruling in Gomez v. Perez (409 U.S. 535) overturned state laws exempting men from financial responsibility for illegitimate

\footnotetext{
${ }^{3}$ In 1978 the US Supreme Court (Zablocki v. Redhail) invoked the Loving decision when holding that a Wisconsin law requiring non-custodial parents to seek a court order (to prove that they were not behind in child support payments) prior to receiving a marriage license was unconstitutional. Similarly, in 1987 Loving was cited in a decision that overturned a regulation that prohibited inmates from marrying without the permission of the warden (Turner v. Safley1987).
} 
children. These rulings reduced both the social and economic cost of bearing a child out-of-wedlock, and thus may help to explain the decline in shotgun marriages. This remains an under-researched topic in need of further scrutiny.

During this period, states also began to consider reducing their role in divorce proceedings. In the 1950s, most states required evidence of marital fault before allowing a marriage to be dissolved. Beginning in the late 1960s, many states introduced "irreconcilable differences" as grounds for divorce; effectively ushering in a period of unilateral divorce — divorce upon the request of either spouse, regardless of the wishes of his or her partner. In addition to the passage of unilateral divorce laws during this period, many states removed fault as a consideration in property division and some states changed laws governing property division subsequent to divorce. Currently all but five states have some form of unilateral divorce and two-thirds allow unrestricted unilateral divorce.

These legal changes fundamentally alter the basis of the marriage contract. They remove the ability to make intertemporal contracts within marriage—one spouse cannot promise not to leave his or her spouse in the future. They shift the right to divorce (and hence bargaining power) from the party most interested in preserving the marriage to the person who most wants out of the marriage. While the old laws had allowed divorce only if there was sufficient evidence of fault, many divorces involved couples where there was mutual consent to divorce. These couples used private bargaining to determine uncontested (and often manufactured) claims of fault to present to the courts. Thus, the fault-based system essentially allowed mutual consent divorce, but not unilateral divorce.

Becker, Landes, and Michael (1977) argued that the divorce rate would be unaffected by a shift from consent to unilateral divorce laws. They argued that this shift simply represents the reallocation of an existing property right from one spouse to the other-namely the right of oneself or one's spouse to remarry. Invoking the Coase theorem, they suggested that "the allocation of property rights or legal liability does not influence resource allocation when the parties involved can bargain with each other at little cost.” Yet the assumptions required for Coasian bargaining, including symmetric information, 
transferable utility, and the absence of important transaction costs, may be unrealistic for the marginal divorce.

Many empirical papers have investigated whether unilateral divorce laws have led to a rise in the divorce rate with several reaching conflicting findings (Peters, 1986 and 1992, Allen 1992, Friedberg 1998). Most recently, Wolfers (2006) tests these competing views by analyzing divorce rates and divorce laws across U.S. states from 1956-1998. He finds that divorce rates rose sharply in the two years following the adoption of unilateral divorce laws, as the courts catered to pent-up demand for divorce. Subsequently, the divorce rate reverted back toward earlier levels, and a decade after these reforms there is no discernable effect on the divorce rate. Despite apparent conflict in this literature, it is worth emphasizing the point of substantial agreement: each of these authors finds that liberalized divorce laws had at most a small effect on divorce rates, and these reforms explain very little of the rise in divorce over the past half century.

While Coasian bargaining predicts little change in divorce rates, it does predict changes in intra-household distribution, as these changes affect each spouse’s options outside marriage, and hence their bargaining position. Stevenson and Wolfers (2006) find that female suicide and domestic violence fell in states that adopted unilateral divorce laws. They interpret these findings as suggesting that unilateral divorce laws shift bargaining power to women. These laws may also affect both the likelihood of marriage and intertemporal decision making within marriage. Rasul (2006) finds that the reduced gains from marriage under unilateral divorce led to a decrease in marriage rates. Research by Stevenson (2007) focuses on the difficulty in intertemporally contracting when marriages can be unilaterally dissolved. Analyzing a sample of newlyweds (so as to minimize selection due to changes in divorce), she finds that the adoption of unilateral divorce laws led to a decrease or delay in several forms of investment whose returns are at least partly marriage-specific, including having children, household specialization, and the financial support of a spouse’s education. 


\section{Shocks to the Marriage Market Matching Function}

A key insight of "search" models of the labor market is that the ease with which workers can locate relevant job openings determines equilibrium employment, unemployment duration, and bargained wages. So too, in the marriage market, the ease with which potential partners can meet and decide whether to date affects if, when, and to whom marriage occurs. Moreover, changes in the marriage market "matching function" have effects beyond the dating phase, as an important factor shaping behavior within marriage is the threat that a spouse may file for divorce-a threat whose impact is shaped by an assessment of one's likely chances on the remarriage market.

McKinnish (2006) provides intriguing evidence of a shock to matching: increasingly sexuallyintegrated workplaces now create greater opportunities for men and women to meet. Analyzing data from the 1990 census, she shows that working in an industry or occupation comprised of a greater share of members of the opposite sex is more likely to lead a marriage to end in divorce, a phenomenon she labels "another form of on-the-job search.” While she does not analyze effects on marriage, these effects could plausibly go in either direction: the increased likelihood (and speed) with which one meets an acceptable spouse could increase marriage, while greater current, and future, exposure to potential mates raises the option value of remaining single. A related shock to future marital patterns—and surely a useful focus for future research—comes from sharply changing gender ratios on college campuses: Goldin, Katz and Kuziemko, 2006, report that while women were a distinct minority of undergraduates in 1960, they are now a clear majority.

The potential of the Internet to increase the efficiency of matching provides another important shock. Indeed, it inspired a bold claim in Wired (Griscom, 2002): "Twenty years from now, the idea that someone looking for love without looking for it online will be silly, akin to skipping the card catalog to instead wander the stacks because 'the right books are found only by accident'... serendipity is the hallmark of inefficient markets, and the marketplace of love, like it or not, is becoming more efficient.” Data from Forrester Research suggests that in 2004, 16 percent of singles are using online 
personals, and a September 2005 Internet Tracking Poll suggests that 3 percent of internet users who are currently coupled first met online. ${ }^{4}$ Online search differs from offline search in two important ways: it expands the set of potential partners and it affords a degree of anonymity. Each of these characteristics shapes the contours of online dating. For instance, Forrester data suggest that over onethird of those using online personals are currently married.

The Internet's potential to change matching is perhaps greatest for those facing thin markets or difficulty in meeting potential mates. Indeed, the Forrester data reveals that those who perceive themselves as facing such markets are more likely to use online personals: blacks and Asians are three times as likely as whites, those with physical disabilities are twice as likely as those without, and gays are four times as likely as straights. Not surprisingly then, several large dating sites exist to serve these niche matching markets, including various ethnic groups, gays, lesbians, the elderly, farmers, persons living with specific disabilities, and those who are HIV-positive.

The larger mainstream dating sites also allow for narrowly-tailored searches, reversing the typical temporal pattern of courtship from assessing attraction before suitability, to one in which couples can ensure that they are appropriately matched on information about religion, fertility and marriage aspirations, income or other important factors, before ever meeting. While this may hark back to the days of parents selecting suitable mates for their children, these matches may be importantly different in the characteristics desired for matching than those selected by parents or other matchmakers. The targeted search offered by the Internet might lead one to forecast greater endogamy (within-group matching). Hitsch, Hortaçsu, and Ariely (2006) examine the characteristics of couples whose dates were arranged through an online dating service, and find, however, that the correlations of characteristics such as age, height, weight, beauty, income, and education were qualitatively similar to

\footnotetext{
${ }^{4}$ Forrester data are author's calculations using Forrester's 2004 Technographics Benchmark Survey (sample size: 55,000). The Internet Tracking Poll is done by the Pew Internet \& American Life Project and Princeton Survey Research Associates International, September 14-December 8, 2005.
} 
those observed among married couples. Yet even within these groups, Internet search allows for the selection of mates with similar consumption and leisure preferences (e.g. “must love dogs”).

While the Internet may yet transform marriage markets, it is too early to assess whether those matched on the Internet are better matched than they would have been without the Internet, whether marriage rates will subsequently rise, and what impact this will have on divorce. The tremendous amount of search being done online by those already married is potentially a harbinger of rising divorce rates, yet this affect may be ameliorated by improved match quality in new marriages.

Finally, search and matching can have an important role in amplifying shocks to the marriage market. For instance, Chiappori and Weiss (2000) note that if the divorce rate rises, then-assuming undirected search—one might meet more divorcees in the course of a day. Thus, were one to divorce, the probability of remarrying is higher, making divorce a more attractive option; this thick market externality creates a self-reinforcing rise in divorce.

\section{Interpreting the Evidence}

Our analysis of the family has pointed to trends in family life and possible driving forces, but we have provided little interpretation of the welfare implications of these trends. Without some discussion of welfare, drawing conclusions about desirable family policies is impossible. We hope to stimulate further research on these issues.

A common argument for a policy response to recent trends notes that, on average, divorced people are worse off-and married people better off_-financially, physically, and emotionally. These associations often lead to the recommendation that policymakers should focus on reducing the rate of marital dissolution, or on promoting marriage (for instance, Waite and Gallagher, 2000). Yet, there is little hard evidence that these policies would be welfare-enhancing. Instead, these policy prescriptions are founded on an assumption that divorce causes people to be worse off, rather than that people who 
are worse off face a greater risk of divorce. Furthermore, it is important to differentiate between the average marriage — which is likely a happy one — and the marginal marriage that may be created or spared by government policy, which may be quite different.

Indeed, the economic theory of the family points precisely in this direction. Becker, Landes, and Michael (1977, p. 1144) argue that "the majority of divorces results from uncertainty and unfavorable outcomes.” Thus, we would expect to see those who suffer adverse shocks to be more likely to both divorce and remain unmarried following a divorce, thereby contributing disproportionately to the stock of the currently divorced. Empirical research has found evidence for such a pattern: Charles and Stephens (2004) find that the divorce hazard rises following a spouse’s layoff and they suggest that this increased probability of divorce stems from the information conveyed about the person's suitability as a spouse, rather than stemming directly from financial losses.

The theory of the family also suggests that marriage is most likely to occur when the potential gains from marriage are large. Individuals with high earning potential have more to gain from domestic arrangements that allow them to specialize in market production; those with a "love of fun" have more to gain from shared leisure and consumption; and those with good health have more to gain due to the greater potential longevity of their marriage. Thus, we should expect that the wealthy, healthy, and happy are more likely to marry. Indeed, even as surveys show that married people are happier than those who are not married, our analysis of self-reported happiness and marital histories in the British Household Panel Survey reveals that singles who are the happiest are also the most likely to marry in the future. If we follow those who were single in 1996 through time, we find that those who married by 2004 experienced gains in happiness similar to gains experienced by those who didn’t marry. Similarly, Gardner and Oswald (2006) find that while people are less happy the year that they separate, a year after the divorce they are happier than they were while married.

Ultimately, purely observational studies cannot convincingly establish whether people are better or worse off as a result of marriage or divorce. The problem is that a number of factors linking 
wellbeing and marital status are unobservable to the researcher. One response is to seek natural experiments that may lead to a sort of random variation across marital status. A small number of quite promising studies have taken this tack and found quite surprising results. For instance, an earlier literature had shown that the economic status of divorced women was lower than that for married women, a fact that had led to concern that divorce impoverishes women (rather than a concern that low income drives divorce). Bedard and Deschênes (2005) exploit the fact that divorce is more likely to follow if the first child born is a girl than a boy to assess the effects of those "random" divorces caused by child gender. They find that divorced women have higher household income and annual earnings than never-divorced women, a fact that is attributable to divorced women working more intensively and the potential for divorced women to join higher income households (such as their parents'). In another study, Dahl (2006) uses variation in state laws restricting the minimum age of marriage to show that those who are prevented from marrying while young are substantially less likely to end up living in poverty later in their lives.

Even while these studies seek to separate correlation from causation, they do not provide directly welfare-relevant metrics. For instance, even if we isolate factors that create more or less divorce, these insights would only yield policy recommendations if coupled with an understanding of whether we currently have an efficient number of divorces, too many, or too few. To understand this point, consider an analogy to the labor market. The U.S. labor market, like its marriage markets, differs from Europe in having substantially greater "churn”; in any given month in the U.S., workers are more likely to be fired, and those without a match are more likely to be hired, than are their European counterparts. There is an emerging consensus that restrictions on churning in European labor markets yields inefficient labor markets, with "too few" job separations. We do not mean to infer by analogy that Europe is afflicted with too few divorces. Rather, we highlight this parallel because it makes the case that a combination of empirical work, attention to causal inference, and general equilibrium theorizing are required to assess implications for aggregate well-being changes in 
marriage markets. With the economics of the family now celebrating the $25^{\text {th }}$ birthday of its foundational text (Becker, 1981) we are confident that the next 25 years will provide progress toward this goal. 


\section{References}

Akerlof, George, Janet Yellen, and Michael, Katz (1996) “An Analysis of Out-of-Wedlock Childbearing in the United States” Quarterly Journal of Economics, 111 (2): 277-317.

Aguiar, Mark and Erik Hurst (2007) "Measuring Trends in Leisure: The Allocation of Time over Five Decades” Quarterly Journal of Economics, 122(3), forthcoming.

Allen, Douglas W. (1992) “Marriage and Divorce: Comment”, American Economic Review, 82(3).

Becker, Gary S. (1981) A Treatise on the Family, Harvard University Press: Cambridge.

Becker, Gary S., Elizabeth M. Landes, and Robert T. Michael (1977) “An Economic Analysis of Marital Instability” Journal of Political Economy, 85 (6): 1141-87.

Bedard, Kelly and Olivier Deschenes (2005) "Sex Preferences, Marital Dissolution, and the Economic Status of Women” Journal of Human Resources, 40 (2): 411-434.

Blau, Francine D. and Lawrence M. Kahn (2000) “Gender Differences in Pay”, Journal of Economic Perspectives, 14 (4): 75-99.

Caucutt, Elizabeth, Nezih Guner, and John Knowles (2002) "Why Do Women Wait? Matching, Wage, Inequality, and the Incentives for Fertility Delay” Review of Economic Dynamics, 5 (4): 815-855.

Charles, Kerwin and Melvin Stephens (2004) "Disability, Job Displacement and Divorce", Journal of Labor Economics, 22 (2): 489-523.

Cherlin, Andrew (1981) Marriage, Divorce, Remarriage, Harvard University Press: Cambridge, MA.

Chiappori, P. A. and Y. Weiss. (2000). "Marriage Contracts and Divorce: An Equilibrium Analysis," mimeo, University of Chicago. http://home.uchicago.edu/ pchiappo/wp/divrevsh.pdf

Coontz, Stephanie (2005) Marriage, a History: From Obedience to Intimacy, or How Love Conquered Marriage, New York: Viking.

Cutler, David, Edward Glaeser, and Jesse Shapiro (2003) "Why Have Americans Become More Obese" Journal of Economic Perspectives, 17 (3): 93-118.

Dahl, Gordon (200) "Myopic Matrimony and Dropout Decisions? Evidence Using State Laws for Marriage, Schooling and Work”, National Bureau of Economic Research Working Paper \# 11328, Cambridge, MA.

The Economist (1999) “Millennium Issue: Oral Contraceptives The Liberator” The Economist Newspaper Dec. 23.

Ellwood, David T. and Jonathan Crane (1990) "Family Change Among Black Americans: What Do We Know?” Journal of Economic Perspectives, 4 (4): 65-84 
Eurostat (2005) Eurostat Yearbook: The Statistical Guide to Europe, Luxembourg: Office for Official Publications of the European Union.

Fitch, Catherin, Ron Goeken and Steven Ruggles (2005), “The Rise of Cohabitation in the United States: New Historical Estimates”, mimeo, University of Minnesota. http://www.hist.umn.edu/ ruggles/cohab-revised2.pdf

Francis, Andrew M. (2006), “The Economics of Sexuality: The Effect of HIV/AIDS on Homosexual Behavior, Desire, and Identity in the United States”, mimeo, Emory University. http://userwww.service.emory.edu/ afranc5/Economics_of_Sexuality.pdf

Friedberg, Leora (1998) “Did Unilateral Divorce Raise Divorce Rates? Evidence From Panel Data”, American Economic Review, 83(3): 608-627.

Gardner, Jonathan and Andrew Oswald (2006) "Do Divorcing Couples Become Happier By Breaking Up?”, Journal of the Royal Statistical Society Series A, 169 (2): 319-336.

Goldin, Claudia and Lawrence Katz (2002) “The Power of the Pill: Oral Contraceptives and Women’s Career and Marriage Decisions”, Journal of Political Economy, 110 (4): 730-70.

Gould, Eric and Daniele Paserman (2003) "Waiting for Mr. Right: rising inequality and declining marriage rates” Journal of Urban Economics, 53 (2): 257-281.

Greenwood, Jeremy, Ananth Seshadri, and Mehmet Yorukogu (2005) “Engines of Liberation” Review of Economic Studies, 72 (1): 109-133.

Greenwood, Jeremy and Guillaume Vandenbroucke (2005) “Hours Worked: Long-run Trends”, National Bureau of Economic Research Working Paper \#11629, Cambridge, MA.

Griscom, Rufus (2002) “Why Are Online Personals So Hot?”, Wired, Issue 10.11. http://www.wired.com/wired/archive/10.11/view.html?pg=2

Carter, Susan B., Scott Sigmund Gartner, Michael R. Haines, Alan L. Olmstead, Richard Sutch, and Gavin Wright. (eds) (2006) Historical Statistics of the United States, Earliest Times to the Present: Millennial Edition, Cambridge University Press: New York.

Hitsch, Guenter, Ali Hortaçsu and Dan Ariely (2006) “What Makes You Click? Mate Preferences and Matching Outcomes in Online Dating”, mimeo, University of Chicago. http://home.uchicago.edu/ ghitsch/Hitsch-Research/Guenter\%20Hitsch_files/Online-Dating.pdf

Jacobson, Paul H. (1959) American Marriage and Divorce, Rinehart and Company, Inc.: New York. Johnson, William H. and Jonathan Skinner (1986) “Labor Supply and Marital Separation”, American Economic Review, 76 (3): 455-69.

Lakdawalla, Darius, Neeraj Sood and Dana Goldman (2006) “HIV Breakthroughs and Risky Sexual Behavior”, Quarterly Journal of Economics, 121 (3): 1063-1102. 
Lam, David (1988) "Marriage Markets and Assortative Mating with Household Public Goods:

Theoretical Results and Empirical Implications”, Journal of Human Resources, 23 (4): 462-87.

Michael J. Brien, Lee A. Lillard and Steven Stern (2006) "Cohabitation, Marriage, and Divorce in a Model of Match Quality”, International Economic Review, 47(2): 451-494.

Lillard, Lee A., Michael J. Brien, and Linda J.Waite (1995) "Pre-Marital Cohabitation and Subsequent Marital Dissolution: A Matter of Self-Selection?” Demography. 32 (3): 437-458.

McKinnish, Terra (2006) "Sexually-Integrated Workplaces and Divorce: Another Form of On-the-Job Search” Journal of Human Resources, forthcoming.

Peters, H. Elizabeth (1986) "Marriage and Divorce: Informational Constraints and Private Contracting”, American Economic Review, 76 (3): 437-54.

Peters, H. Elizabeth (1992) “Marriage and Divorce: Reply”, American Economic Review, 82(3): 686693.

Rasul, Imran (2006) “The Impact of Divorce Laws on Marriage”, mimeo, University College, London.

Statistics Canada (2004) “The Canada Year Book”, online edition available at: www.statcan.ca.

Stevenson, Betsey and Justin Wolfers (2006) "Bargaining in the Shadow of the Law: Divorce Laws and Family Distress”, Quarterly Journal of Economics, 121 (1): 267-288.

Stevenson, Betsey (2006) “Divorce-Law Changes, Household Bargaining, and Married Women’s Labor Supply Revisited”, mimeo, University of Pennsylvania.

Stevenson, Betsey (2007) “The Impact of Divorce Laws on Investment in Marriage-Specific Capital”, Journal of Labor Economics, 25 (1): 75-94

U.S. Census Bureau (2005) Current Population Survey, March and Annual Social and Economic Supplements, 2005 and earlier. http://www.census.gov/population/socdemo/hh-fam/ms2.pdf

U.S. Census Bureau (2007) Statistical Abstract of the United States, Washington, DC.

Waite, Linda J. and Maggie Gallagher (2000) The Case for Marriage, New York: Random House.

Wolfers, Justin (2006) “Did Unilateral Divorce Raise Divorce Rates? A Reconciliation and New Results”, American Economic Review, 96(5) 1802-1820. 
Figure 1: Marriage and Divorces per Thousand People 1860-2005

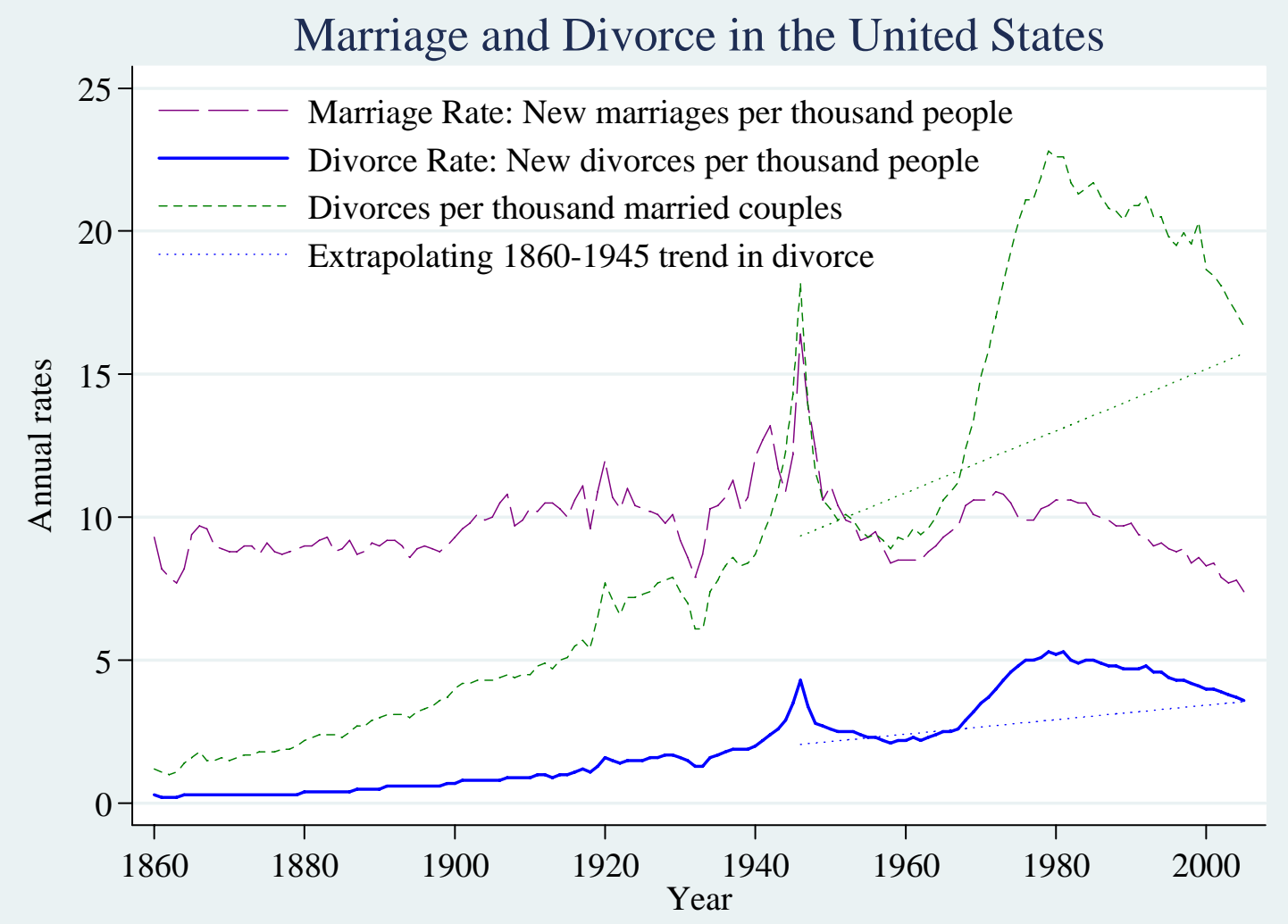

Sources: For the United States, data for 1860-1919 are from Jacobson (1959); 1920-1998 from Carter et. al. (2006), Historical Statistics of the United States, Millenium Edition; 1999-2005 from Statistical Abstract of the United States. 
Figure 2

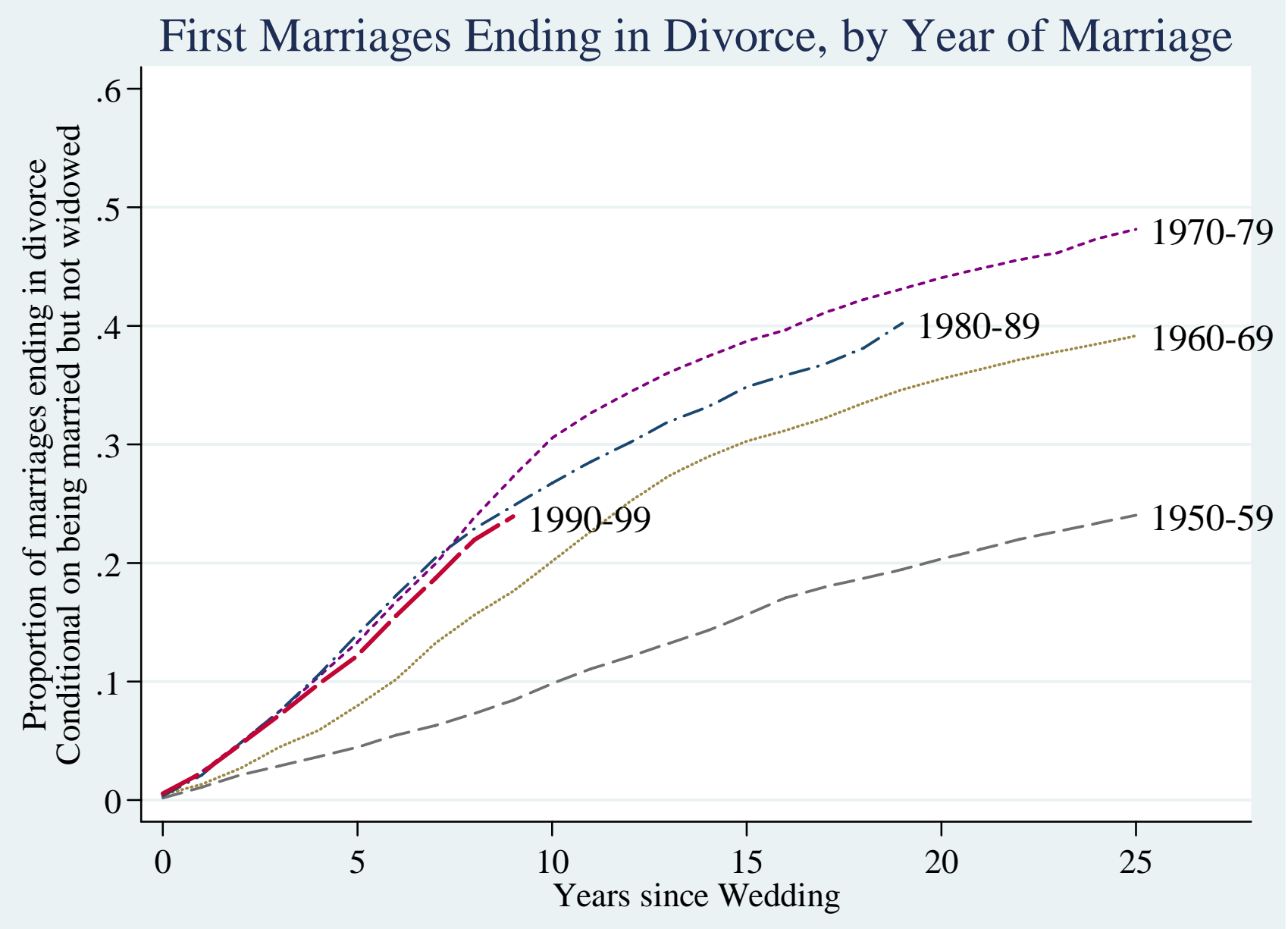

Source: Retrospective marital histories recorded in the 2001 Survey of Income and Program Participation. 
Figure 3: Percent Married by Age 1880-2004

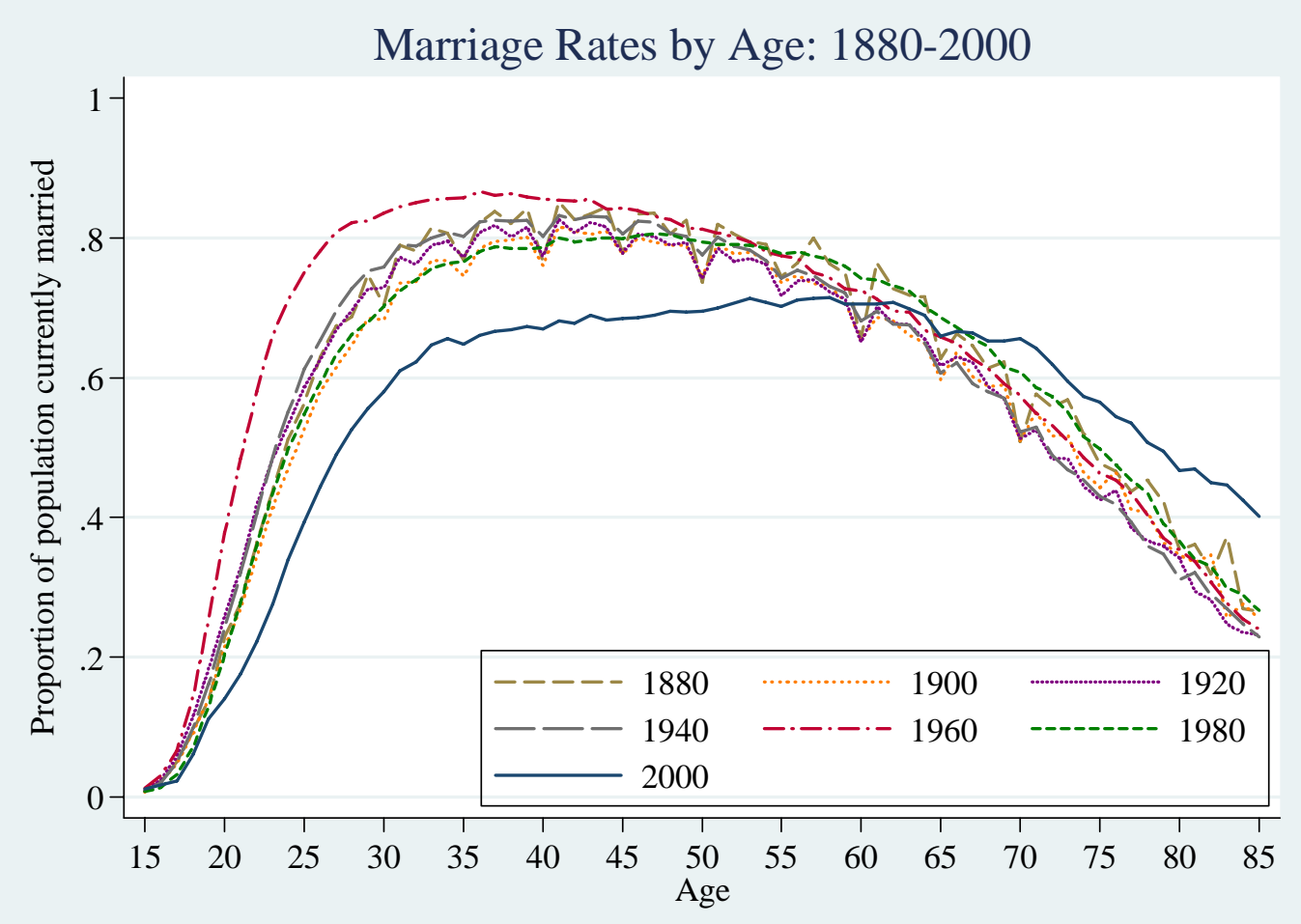

Source: U.S. Censuses of Population, 1880-2000.

Figures -3 
Figure 4

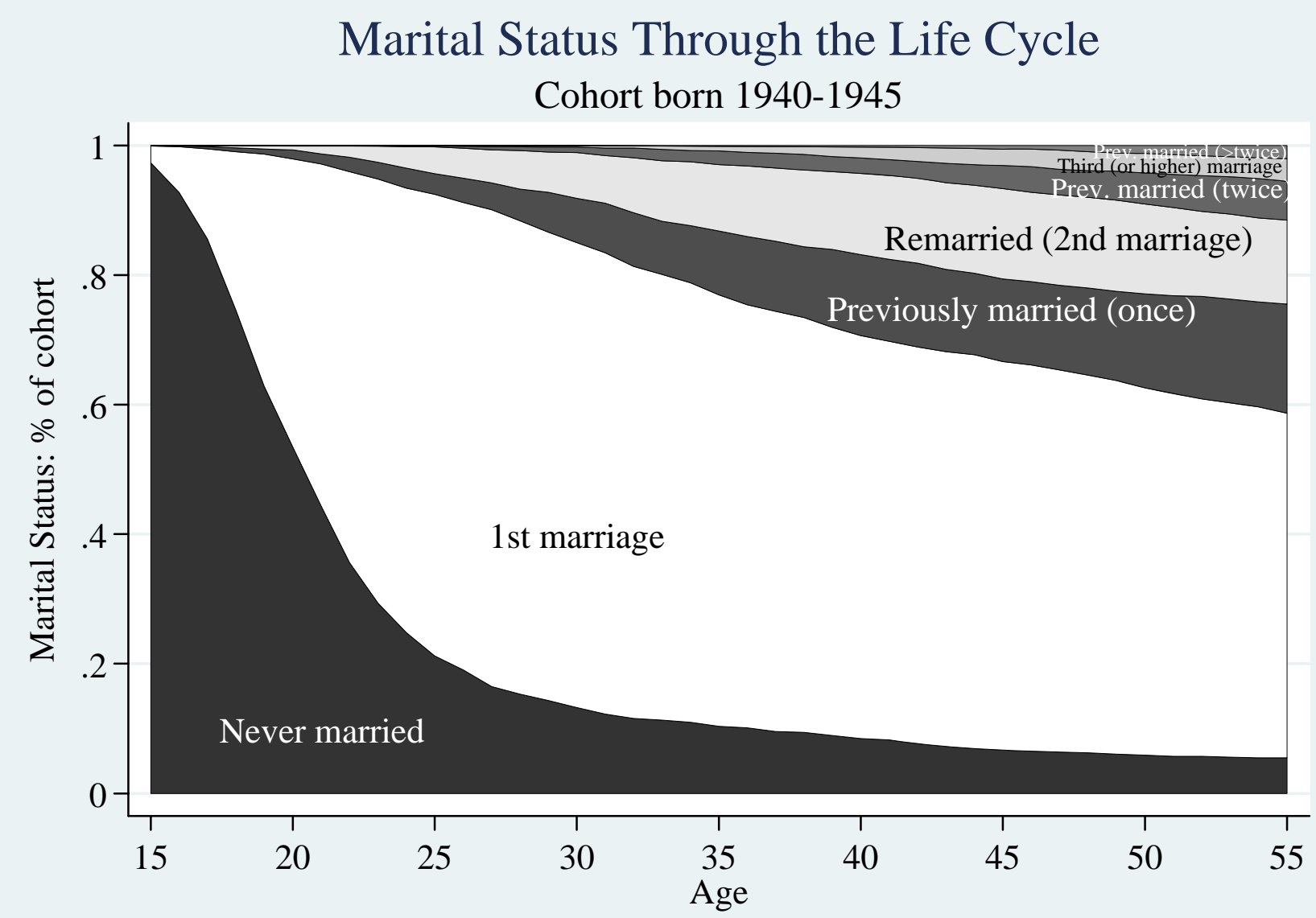

Source: SIPP 2001 Marital History module.

Figures - 4 


\section{Figure 5}

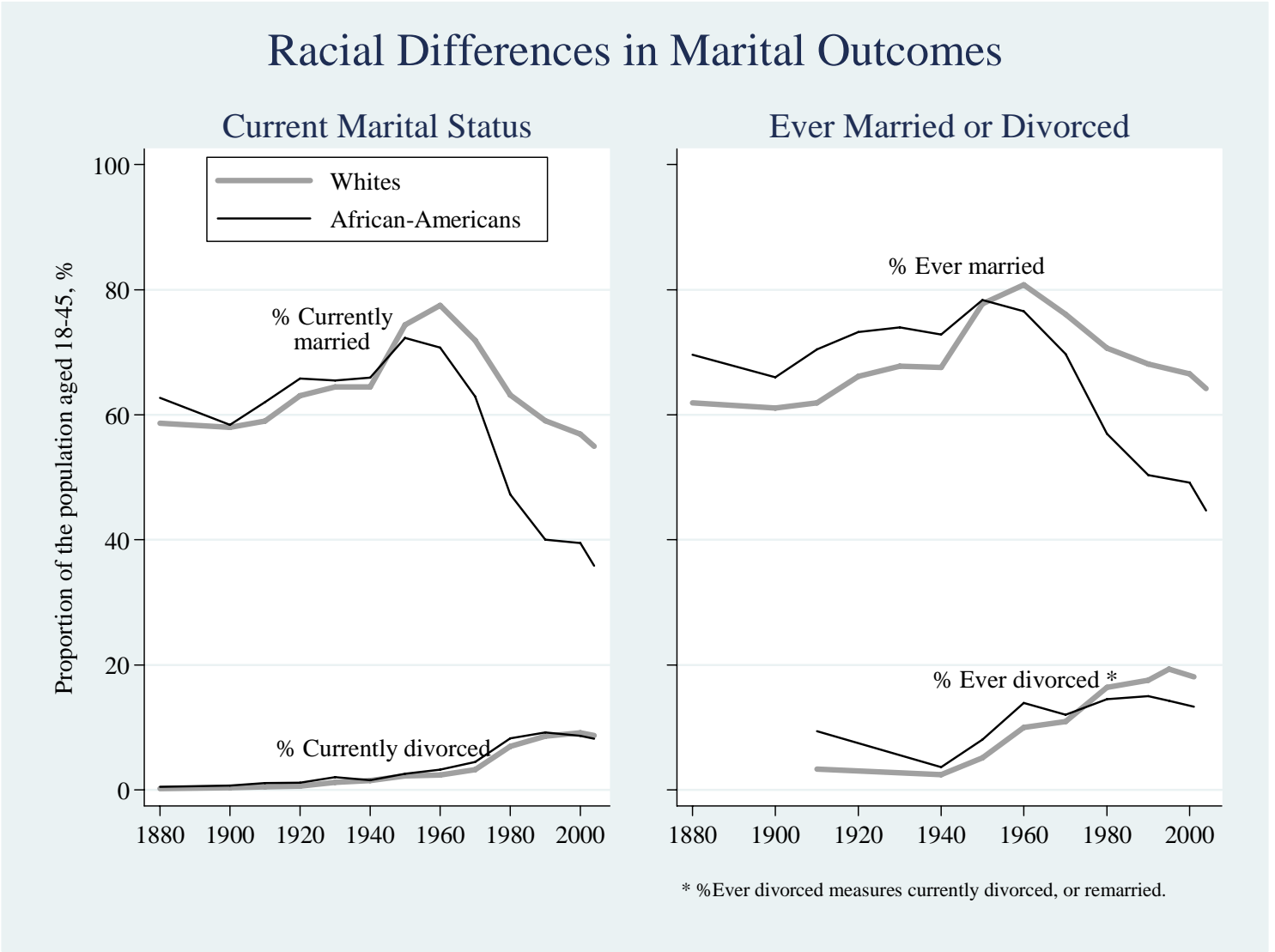

Sources: Census 1880-2000; American Community Survey 2004; Ever-divorced from 1910, 1940-1980 census, supplemented by 1990, 1995 CPS and 2001 SIPP marital history supplements. 


\section{Table 1}

\section{Marital Life Cycle: Outcomes by Age 45 Across Cohorts, Time, Education and Race}

\begin{tabular}{|c|c|c|c|c|c|c|c|c|}
\hline & \multirow{2}{*}{\multicolumn{2}{|c|}{$\begin{array}{l}\begin{array}{l}\text { Born } \\
1940-45\end{array} \\
\text { By Cohort }\end{array}$}} & \multicolumn{2}{|c|}{ n 1950-55 } & \multirow{2}{*}{\multicolumn{2}{|c|}{ By Race }} & \multirow{2}{*}{\multicolumn{2}{|c|}{ By Education }} \\
\hline & & & By G & ider & & & & \\
\hline & All & All & Men & Women & Black & White & $\begin{array}{c}\text { College } \\
\text { grads }\end{array}$ & $<$ College \\
\hline \%Ever married & $93.1 \%$ & $89.5 \%$ & $88.2 \%$ & $90.7 \%$ & $77.6 \%$ & $91.0 \%$ & $89.5 \%$ & $89.5 \%$ \\
\hline \multicolumn{9}{|l|}{ Among those ever married: } \\
\hline Average Age at First Marriage & 22.6 & 23.6 & 24.7 & 22.6 & 24.7 & 23.3 & 24.9 & 22.8 \\
\hline \%Still in first marriage & $64.5 \%$ & $56.6 \%$ & $59.1 \%$ & $54.3 \%$ & $52.7 \%$ & $56.1 \%$ & $63.3 \%$ & $52.6 \%$ \\
\hline$\%$ of first marriages ending in divorce & $32.7 \%$ & $40.8 \%$ & $39.4 \%$ & $42.0 \%$ & $42.9 \%$ & $41.5 \%$ & $34.8 \%$ & $44.3 \%$ \\
\hline \multicolumn{9}{|l|}{ Among those who divorced } \\
\hline Average duration of marriage (yrs) & 10.3 & 9.0 & 8.7 & 9.3 & 9.7 & 8.9 & 9.0 & 9.1 \\
\hline \%Remarrying & $70.5 \%$ & $68.9 \%$ & $71.3 \%$ & $66.8 \%$ & $56.8 \%$ & $70.6 \%$ & $67.8 \%$ & $69.4 \%$ \\
\hline \multicolumn{9}{|l|}{ Among those remarrying after divorce } \\
\hline Average time to remarriage (yrs) & 3.9 & 4.2 & 3.9 & 4.5 & 4.7 & 4.2 & 4.2 & 4.2 \\
\hline$\%$ Still in $2^{\text {nd }}$ marriage & $70.7 \%$ & $62.5 \%$ & $64.1 \%$ & $61.0 \%$ & $58.6 \%$ & $63.0 \%$ & $70.2 \%$ & $59.0 \%$ \\
\hline$\%$ of $2^{\text {nd }}$ marriages ending in divorce & $26.5 \%$ & $35.7 \%$ & $35.3 \%$ & $36.2 \%$ & $36.1 \%$ & $35.7 \%$ & $28.7 \%$ & $39.0 \%$ \\
\hline \multicolumn{9}{|c|}{ Among those whose $2^{\text {nd }}$ marriage ends in divorce } \\
\hline Average duration of $2^{\text {nd }}$ marriage (yrs) & 6.7 & 6.0 & 6.1 & 5.9 & 6.4 & 6.0 & 5.7 & 6.1 \\
\hline \%Remarrying & $49.2 \%$ & $53.0 \%$ & $55.8 \%$ & $50.5 \%$ & $49.1 \%$ & $54.1 \%$ & $49.9 \%$ & $54.1 \%$ \\
\hline
\end{tabular}

Source: Authors calculations based on retrospective marital histories collected in the 2001 Survey of Income and Program Participation. 


\section{Table 2}

\section{International Comparisons}

(latest statistics, typically around 2003)

\begin{tabular}{|c|c|c|c|c|c|c|c|}
\hline & U.S. & Canada & UK & France & Germany & Italy & Sweden \\
\hline \multicolumn{8}{|l|}{ Marriage } \\
\hline Annual marriages per thousand people & 7.4 & 4.7 & 5.1 & 4.3 & 4.8 & 4.3 & 4.8 \\
\hline $\begin{array}{l}\text { Annual marriages per thousand unmarried } \\
\text { adults }\end{array}$ & 18.1 & 13.0 & 11.4 & 9.4 & 12.1 & 10.8 & 8.8 \\
\hline$\%$ of adult population currently married & $59.6 \%$ & $62.9 \%$ & $55.1 \%$ & $54.3 \%$ & $60.4 \%$ & $60.0 \%$ & $45.2 \%$ \\
\hline$\%$ of adult population ever married & $76.9 \%$ & $75.5 \%$ & $72.0 \%$ & $69.5 \%$ & $75.9 \%$ & $72.8 \%$ & $64.3 \%$ \\
\hline $\begin{array}{l}\text { Remarriage (\% of marriages in which the } \\
\text { bride was previously married) }\end{array}$ & $28.4 \%$ & -- & $28.9 \%$ & $17.6 \%$ & $28.3 \%$ & $6.3 \%$ & $23.7 \%$ \\
\hline $\begin{array}{l}\% \text { of } 2002 \text { marriages in which the bride was } \\
35 \text { years old or over }\end{array}$ & $31 \%$ & $28 \%$ & $30 \%$ & $28 \%$ & - & $15 \%$ & $33 \%$ \\
\hline \multicolumn{8}{|l|}{ Divorce } \\
\hline Annual divorces per thousand people & 3.6 & 2.2 & 2.8 & 2.1 & 2.6 & 0.8 & 2.2 \\
\hline $\begin{array}{l}\text { Annual divorces per thousand married } \\
\text { people }\end{array}$ & 8.5 & 4.6 & 6.9 & 5.1 & 5.7 & 1.3 & 6.8 \\
\hline$\%$ of adult population currently divorced & $10.2 \%$ & $4.9 \%$ & $8.3 \%$ & $6.7 \%$ & $6.3 \%$ & $9.6 \%$ & $11.3 \%$ \\
\hline \multicolumn{8}{|l|}{ Cohabitation } \\
\hline $\begin{array}{l}\% \text { of adult population in non-marital } \\
\text { cohabitation }\end{array}$ & $4.7 \%$ & $10.7 \%$ & $11.6 \%$ & $10.8 \%$ & $7.1 \%$ & $3.9 \%$ & $11.7 \%$ \\
\hline \multicolumn{8}{|l|}{ Fertility } \\
\hline Annual births per thousand people & 14.0 & 10.4 & 11.7 & 12.7 & 8.6 & 9.5 & 11.1 \\
\hline Completed fertility: 1961 birth cohort & 1.96 & -- & 1.95 & 2.10 & 1.63 & 1.63 & 2.03 \\
\hline Mean age at childbirth & 27.3 & 29.0 & 28.8 & 29.5 & 29.1 & 30.3 & 30.3 \\
\hline Non-marital births (\% of all births) & $34.6 \%$ & $36.2 \%$ & $42.3 \%$ & $45.2 \%$ & $28.0 \%$ & $14.9 \%$ & $55.4 \%$ \\
\hline \multicolumn{8}{|l|}{ Attitudes: \% Agree that... } \\
\hline Marriage is an out-dated institution & $10.1 \%$ & $22.3 \%$ & $25.9 \%$ & $36.3 \%$ & $18.4 \%$ & $17.0 \%$ & $20.4 \%$ \\
\hline $\begin{array}{l}\text { People who want children ought to get } \\
\text { married }\end{array}$ & $65.3 \%$ & $48.9 \%$ & $52.4 \%$ & $41.2 \%$ & $52.9 \%$ & $60.9 \%$ & $31.0 \%$ \\
\hline $\begin{array}{l}\text { Divorce is usually the best solution when a } \\
\text { couple can't seem to work out their marriage } \\
\text { problems }\end{array}$ & $43.0 \%$ & $78.0 \%$ & $61.1 \%$ & $61.0 \%$ & $74.8 \%$ & $65.0 \%$ & $54.6 \%$ \\
\hline
\end{tabular}

Sources: Eurostat yearbook; Statistical Abstract of the United States; Canada Yearbook; International Social Survey Programme, 1994 \& 2002; World Values Survey; 2002 Eurobarometer, 2002. 